\title{
Long Lasting Differences in Civic Capital: Evidence from a Unique Immigration Event in Italy
}

\author{
E. Bracco*1 ${ }^{*}$ M. De Paola** and C. Green*
}

\begin{abstract}
A range of evidence exists demonstrating that social capital is associated with a number of important economic outcomes such as economic growth, trade and crime. A recent literature goes further to illustrate how historical events and variation can lead to the development of differing and consequential social norms. This paper examines the related questions of how persistent initial variations in social capital are, and the extent to which immigrant groups do or do not converge to the cultural and social norms of their recipient country by examining a unique and geographically concentrated immigration event in $16^{\text {th }}$ century Italy. We demonstrate that despite the substantial time since migration these communities still display different behavior consistent with higher civic capital than other comparable Italian communities. Moreover, we demonstrate that this difference does not appear to have changed over the last 70 years. For instance, differences in voter turnout apparent in the late 1940s remain in the $21^{\text {st }}$ century. This latter finding has implications for our view of the likelihood of assimilation of immigrant groups to local norms, particularly in cases of large-scale migration.
\end{abstract}

JEL classification:D72, J15, Z10

Keywords: Social Capital; Electoral Turnout; Migration; Persistence

* Department of Economics, Lancaster University

** Department of Economics, Statistics and Finance, University of Calabria

\footnotetext{
${ }^{1}$ We would like to thank for his extremely useful suggestions Francesco Altimari. We also thank for comments and suggestions Giuseppe Albanese, Francesca Gioia, Matteo Ploner, Vincenzo Scoppa, and seminar participants to the Italian Public Economics Society, Pavia, 2013, the European Public Choice Society, April 2014, Cambridge, the Italian Economics Society, October, 2014.

Corresponding author: Emanuele Bracco, Department of Economics, Lancaster University. Email: e.bracco@lancaster.ac.uk. Tel: +44 (0) 1524592728
} 


\title{
Long Lasting Differences in Civic Capital: Evidence from a Unique Immigration Event in Italy
}

\begin{abstract}
A range of evidence exists demonstrating that social capital is associated with a number of important economic outcomes such as economic growth, trade and crime. A recent literature goes further to illustrate how historical events and variation can lead to the development of differing and consequential social norms. This paper examines the related questions of how persistent initial variations in social capital are, and the extent to which immigrant groups do or do not converge to the cultural and social norms of their recipient country by examining a unique and geographically concentrated immigration event in $16^{\text {th }}$ century Italy. We demonstrate that despite the substantial time since migration these communities still display different behavior consistent with higher civic capital than other comparable Italian communities. Moreover, we demonstrate that this difference does not appear to have changed over the last 70 years. For instance, differences in voter turnout apparent in the late 1940s remain in the $21^{\text {st }}$ century. This latter finding has implications for our view of the likelihood of assimilation of immigrant groups to local norms, particularly in cases of large-scale migration.
\end{abstract}

JEL classification:D72, J15, Z10

Keywords: Social Capital; Electoral Turnout; Migration; Persistence 


\section{INTRODUCTION}

A range of evidence exists that demonstrates a relationship between social capital and important socioeconomic outcomes. Using a variety of proxies, social capital has been shown to have substantial predictive power across a range of domains, including economic growth (Helliwell and Putnam, 1995; Knack and Keefer, 1997; Zak and Knack, 2001), trade (Guiso et al., 2008), well-functioning institutions (Knack, 2002), corruption and crime (Uslaner, 2002; Buonanno et al., 2009) and well working financial markets (Guiso et al., 2004). While this literature demonstrates large and long-lived within and across country differences in values and social norms, rather less is known about the origins of these differences.

Recently a body of research has developed which aims to examine the formulation of different types of social capital. Generally this literature analyzes the relationship between historical events or historical sources of variation and current levels of social capital. For instance, Durante (2010) demonstrates how trust developed in pre-industrial times as a form of mutual insurance for agrarian societies to cope with climatic risk. He shows that contemporary surveyed variation in trust across Europe is positively related to higher temporal volatility in climatic conditions in the $16^{\text {th }}$ century. In a similar vein, Nunn and Wantchekon (2011) relate current levels of trust within Africa to historical variation in the geography of slave-trade related raids. While Tabellini (2010) shows that current civic values in Italy are correlated with historical variables (political institutions in the period from 1600 to 1850) and that the component of culture explained by history is in turn correlated with current regional economic development. Other research on Italy examines the link between geographical variation in casualties during the unification process that may have undermined trust towards authorities and election turnout (Amodio, 2012); or the emergence of free-city states in the Middle Ages, the formation of informal pacts, and social capital (Guiso et al., 2008). Jacob and Tyrell (2010) show how the density of Stasi informers in the former GDR is negatively related to social capital levels in today's East Germany. The persistence in social norms is also documented by Voigtländer et al. (2014), who find that localities where pogroms against Jews took place during the Black Death epidemic in the $14^{\text {th }}$ century showed higher levels of deportations and persecution of Jews 600 years later, during the interwar period. In addition, Voigtländer and Voth (2014) find that the support to anti-Semitic parties in Germany in 1890 and 1920-30s is strongly correlated with anti-Semitic attitudes expressed in opinion surveys in 1996 and 2006.

While this literature suggests long-lasting differences in social capital there is other work demonstrating how social capital can be influenced by contemporaneous factors, and hence should be viewed as malleable. Much of this literature shows that social capital can be adversely affected by increasing 'openness', migration and the mixing of communities. For instance, Di Pasquale and Glaeser (1999) show that expected mobility reduces social capital, while Alesina and La Ferrara (2000), Costa and Kahn (2003) and Freire and Li (2013) argue that social capital is affected by inequality and the 
heterogeneity of communities. These results are in line with the theoretical model proposed by Glaeser et al. (2002) according to which social capital investment increases when the return to social skills is higher and in communities with higher aggregate social capital, while it tends to decreases with age and relocation to a different community. According to these arguments, the increased mobility that has been witnessed over the past two centuries should act to dissipate differences in social capital across individuals or groups of individuals.

This paper contributes to this literature but takes a different tack. Specifically, we focus on a unique immigration event in Italy that was geographically concentrated. This allows us to ask a number of questions related to how persistent initial variations in social capital are over time, but at the same time to shed light on issues related to the cultural and social assimilation of immigrant groups. We focus on the settlement of large groups of Albanians into southern Italy following the invasion of the Balkans by the Ottoman Turks in the late $16^{\text {th }}$ century. Importantly, these groups moved to geographically clustered villages within southern Italy. They were granted hospitality and some privileges by the local hosting barons and still now their descendants live in some southern Italian villages, whose inhabitants are called Arbëreshë.

They have essentially lived peacefully in southern Italy for more than 500 years. This may reflect the fact that their way of life did not disturb the status quo. Some villages formerly populated by Albanian have lost their Albanian traits, while others (around 40) scattered in five regions (Apulia, Basilicata, Calabria, Molise, Sicily), in the southern part of Italy, still preserve a distinct language (they speak Arbërisht, an old variant of Albanian) and/or a distinct religious rite (Greek Orthodox).

The main thrust of our paper is to investigate whether these populations show different levels of civic capital compared to "Italian" groups living in the same geographical area. This is an interesting setting in so far as Southern Italy is noted for its poor endowment of social capital (see for instance, Bertoni et al, 2013 and Paccagnella and Sestito 2014). The Arbëreshë people, apart from preserving a distinct language, may have preserved distinct social values, which could be pre-determined or the result of their attempt to be accepted in a hosting country.

We show that this group of individuals displays significantly higher levels of civic capital than comparable indigenous groups. Moreover, this is observable for a period (immediate post war) where there was limited inter-regional mobility and interaction with other areas; but has not diminished markedly in the following half century when mobility substantially increased. This result is important as it demonstrates how substantial variations in civic capital can be created by specific historical episodes, and that these differences may be very long lasting. This latter point is of clear interest if one considers, as per the literature highlighted above, that social capital has a key role in explaining cross-country and within- 
country variations in institutional and economic performance. In addition, our result is of interest insofar as it has implications for the role of large-scale migration on social norms.

To deal with the endogeneity issues that might plague our results we firstly look at successively more restrictive geographic comparisons: more proximate areas should differ less in terms of unobserved characteristics that influence both civic capital and voter turnout. Then, as an alternative strategy we adopt an instrumental variable approach `and use as a source of variation the historical location of two seminaries that contributed greatly to the preservation of the Arbëreshë culture. Our results remain qualitatively unchanged and instrumental variable estimates are larger in magnitude compared to OLS estimates, suggesting that unobservable confounding factors produced a downward bias.

We extend this in an attempt to examine whether differences in voting behavior are likely driven by underlying differences in civic attitudes. Typical proxies for social capital (blood donations, crimes etc) are available only at a provincial level and hence not suitable for our analysis. Instead, we use municipality level data sourced from RAI TV on the payment of the television license tax. This data allows us to build a measure of tax compliance that we use as an alternative dependent variable in our models. These results, insofar as the Arbëreshë have higher compliance rates, provide a further indication that these communities display 'better' civic behavior. Finally, we provide evidence suggesting that neither population homogeneity nor the retention of the orthodox religion are sufficient explanations of the observed differences in behavior.

The paper is organized as follows. In section II it is provided information on the historical background. Section III discusses the data, while section IV presents the empirical methodology. Section $\mathrm{V}$ presents the main results. Section VI presents instrumental variable estimates while section VII presents further extensions and robustness checks. Section VIII concludes.

\section{BACKGROUND}

We focus on a unique migration event that occurred in Italy in the late $16^{\text {th }}$ century following the invasion of the Balkans by the Ottoman Turks. There is a general agreement that the migration period was from 1448 to 1543 and that there were three main waves (see Scaglione, 1921, and Zangari, 1940). The first two migrations waves (1448-1459) were the consequence of the political alliance between the Albanian chieftain George Kastrioti Skanderbeg, who unified the Albanian tribes against the Ottoman invasion, and the Italian aristocracy (Pedio, 1943). In two occasions (in 1448 and in 1459 respectively) the king of Naples appealed to Skanderbeg for aid in suppressing revolts. After the military interventions the Albanian mercenaries asked and obtained hospitality, settling in a number of villages. The main migration wave was the third one occurring immediately before the defeat of the Albanian resistance (1480) when the hope of victory over the Turks began to fade. From 1470 to 1480 many Albanians received hospitality 
in southern Italy. They were directed towards specific territories based on the necessity of repopulating some areas and to fill the lack of labor in some feudal areas, avoiding, at the same time, too much concentration of Albanians and potential conflict with local populations. The Albanian immigrants were accepted by the local barons and obtained some privileges, such as the right to speak their own language and tax relief. The Pope allowed them to keep the Greek-Byzantine rite and exempted them from paying tributes to the Church. ${ }^{2}$ These facts might have shaped the expectations of trustworthiness towards the political authority. In addition, these people, being refugees in a hosting country, might have built social ties among them and developed cooperative attitudes enabling them to achieve collective goods. This process is at the origin of the development of several communities in the South of Italy: many villages in the regions of Apulia, Basilicata, Calabria, Molise and Sicily, were founded or repopulated by Albanians. A variety of historical sources report that in the $17^{\text {th }}$ century about a hundred Italian villages were populated primarily by Albanians. ${ }^{3}$

No reliable historical sources exist that establish whether these migrants, compared to the indigenous populations living in the same areas, were from a 'better' social background. However, modern historians argue that Albanian high-caste dignitaries were not present among the refugees of the $16^{\text {th }}$ century nor among the other migration waves. Instead, these immigrants were ordinary people accompanied by a few Orthodox priests. Similar to the other populations living in the area, they were mainly shepherds, farmers, peasants, while nobles and wealthier people moved to major towns, such as Venice, Naples and Palermo (Bugliaro, 2002). Nevertheless, we are not able to establish whether these immigrants left their country with different resources in terms of both human and social capital and whether these endowments were passed on to following generations.

Possibly as a consequence of the fact that their way of life did not disturb the status quo, and because they have been in many circumstances loyal to the Italian state, the Arbëreshë were accepted and they have lived peacefully in southern Italy for more than 500 years. The Arbëreshë have never had a political or ethnic conflict with the Italian State and never claimed or desired separation or autonomy. Instead, they consider themselves Italians who in addition have Albanian origins (Derhemi, 2002). ${ }^{4}$ The Arbëreshë strongly contributed to the Italian Risorgimento and to the military campaigns that lead to the country unification in 1861 . To give an idea of the role played by this minority in the Italian unification

\footnotetext{
${ }^{2}$ Thanks to the intervention of Pope Paul II many local barons granted them land at better conditions that those granted to indigenous Italian populations. However, during the Counter Reformation the Catholic Church tried to impose its own rite with partial success.

${ }^{3}$ A small number of ethnic Albanians were present in Italy before this time.

${ }^{4}$ Arbëreshë elite families actively sought integration in Italian society through intermarriage, mainly involving members of the Italian elite. Francesco Crispi (1818-1901), one of the former Italian Prime Ministers after the unification of Italy and Antonio Gramsci (1891-1937) a founding member and leader of the Italian Communist Party, were of Albanian descents.
} 
process it is useful to report that three of the six ministers appointed by Garibaldi (who commanded and fought in many military campaigns that led to the formation of a unified Italy) for his provisional government were from Arbëreshë villages. ${ }^{5}$

No information exists regarding which villages were populated by Albanians in the $16^{\text {th }}$ century. Some historical information is available on villages whose origin is thought to have been Albanian but which now retain no or slight traces of their past heritage. ${ }^{6}$ The first reliable information on Albanian communities in Italy is from the 1861 census of the Italian population, which provides information of the share of population speaking the Arbërisht in each village. From this source we found that in 47 villages there was a share of population (ranging from $4 \%$ to $100 \%$ ) speaking Arbërisht. ${ }^{7}$ This share was smaller than $50 \%$ in only five villages, while in the others on average $91 \%$ of the population had preserved the Arbërisht language. The fascist government stopped gathering data on the Italo-Albanian-speaking population and all other minority groups, and this has persisted since. As a result, there are no official statistics on the proportion of the population that still speaks the Arbërisht language.

Currently, the Arbëreshë minority is estimated to number approximately 90,000-100,000 people living mainly in 41 villages in which most of the inhabitants still preserve the Arbërisht language and and/or observe Greek orthodox rites (Altimari and Savoia, 1994). In our analysis we consider as Arbëreshë the 41 villages still now preserving one of these traits. However, our results remain qualitatively unchanged even if we focus on the 45 villages (we exclude the two villages located in Abruzzo and Campania) taken from the 1961 census or if we consider the share of population today speaking the Arbërisht language gathered from a current survey of the mayors of Arbëreshë villages.

According to experts (see Cucci, 2007), a major contributor to the preservation of the Arbëreshë culture comes from the institution, in the $18^{\text {th }}$ century, of two seminaries, one located in Calabria and the other on the island of Sicily. The Collegio Corsini was founded in 1732 in San Benedetto Ullano (Calabria). In 1794 it was moved to San Demetrio Corone and the name changed to Collegio

\footnotetext{
${ }^{5}$ They were Luigi Giura, Pasquale Scura and Francesco Crispi. The Arbëreshë commitment to these political causes is also reflected in their popular songs in which they compare the Italian hero Garibaldi to the Albania hero Skanderbeg (Serra, 1969).

${ }^{6}$ Among the villages whose people have become integrated with the Italians some sources (Nasse, 1964) report: Arlette, Cavallerizzo, Cervicati, Farneta, Gizzeria, Macchia, Porcile, Rota, Vena, Zangarona, Colle di Lauro, Santacroce di Magliano, Sant’Elena Sannita, Bronte, Biancavilla, San Michele di Ganzaria, Sant'Angelo, Faeto, Faggiano, Martignano, Panni, San Paolo

${ }^{7}$ These villages are in Abruzzo (Villa Badessa), Apulia (Casalvecchio di Puglia, Chieuti, Monteparano, San Marzano di San Giuseppe), in Basilicata (Barile, Ginestra, Maschito, San Costantino Albanese, San Paolo Albanese), in Calabria (Acquaformosa, Amato, Andali, Carfizzi, Castroregio, Cerzeto, Civita, Falconara Albanese, Firmo, Frascineto, Lungro, Marcedusa, Mongrassano, Pallagorio, Plataci, San Basile, San Benedetto Ullano, San Cosmo Albanese, San Demetrio, San Giacomo, San Giorgio Albanese, San Martino di Finita, San Nicola dell’Alto, Santa Caterina Albanese, Santa Sofia d’Epiro, Spezzano Albanese, Vaccarizzo Albanese), in Campania (Greci), in Molise (Campomarino, Montecilfone, Portocannone, and Ururi), in Sicily (Contessa Entellina, Palazzo Adriano, Piana degli Albanesi, Mezzoiuso, Santa Cristina di Gela).
} 
Sant'Adriano. In the same period (1734), in Sicily, Palermo, the Greek college later called "Collegio Greco-Albanese” was founded. These seminaries trained members of the Arbëreshë clergy, together with a large number of professionals. These seminaries were important as cultural centers and for the maintenance of the Arbëreshë language and the Greek orthodox rite. ${ }^{8}$ Figure 1 depicts a map of Italy, which highlights the regions interested by the Arbëreshë immigration, and - within those regions - the location of the Arbëreshë villages and of the two seminaries.

\section{DATA}

Arbëreshë villages are in many ways similar to other villages of southern Italy (there are no differences in the house type, land use, diet, clothing, education), however, after more than 500 years from the arrival of their ancestors in a region where they had almost no contact from their homeland, their inhabitants have demonstrated a substantial degree of cultural resilience. The aim of our research is to understand whether these villages display significantly different levels of social capital than comparable indigenous ‘Italian' groups.

A key issue in examining social capital is measurement. As highlighted by Guiso et al (2010), it is increasingly clear that social capital is an ambiguous term that has been invoked in a range of ways that are not necessarily consistent. ${ }^{9}$ Guiso et al (2010) suggest the alternative concept of "civic capital” as a set of values and beliefs that facilitate co-operation. Specifically, it is these "persistent and shared beliefs and values that help a group overcome the free rider problem in the pursuit of socially valuable activities" (Guiso et al, 2010, p.3).

Existing empirical work aimed at measuring civic capital focuses on one of two approaches. The first approach is to use survey responses on questions regarding trust, such as those commonly included in the major value or social surveys. An alternative approach is based on revealed-preference style proxies that are connected to civic capital by some view of socialization; such as charitable giving or election turnout. In this paper, we focus on these latter types of measures, as we believe that these measures are more convincing as stakes are attached to this behavior.

More precisely, we focus on a variety of measures of voter turnout, which fit with a key concept of civic capital, the propensity to cooperate and help in the creation of collective goods (Amodio, 2012; Guiso et al. 2010). While other forms of civic behavior are clearly interesting, a clear advantage of this data for our purposes is that turnout is measured accurately and at a municipality level. We firstly consider

\footnotetext{
${ }^{8}$ In 1805 the Collegio Corsini seminar was transformed in a Lyceum devoted at providing education in classical and scientific studies to the young Arbëreshë.

9 This raises concerns regarding the measurement of social capital, how it can be 'accumulated', and more fundamentally the comparability of research that often uses vastly different proxies to measure its effect.
} 
referenda turnout since this is a measure of social capital widely used in the economic literature. However, as we only have data for the 2011 national referenda, ${ }^{10}$ we also consider European Election turnout for the period 1979-2014. European elections are comparable with referenda since turnout at these elections is unlikely to be driven by economic incentives; ${ }^{11}$ due to these reasons data on these elections have been already used as a proxy of civic capital (see for instance Amodio, 2012; Barone and Mocetti, 2014).

Finally, we also examine participation at the general elections, using data on Italian parliamentary elections of the lower house of the Parliament (Camera dei Deputati). Existing research demonstrates that generalized interpersonal trust and norms of reciprocity are strongly correlated with turnout (Newton, 1997; Putnam, 1995; Putnam, Leonard and Nanetti, 1993; Seligson, 1999). A key advantage of these data is that they cover a relatively long period (1946-2008), which allows us to investigate if civic behavior has changed across the post-war period. Data on turnout at the 2011 referenda and at European elections are provided by the Italian Ministry of the Internal Affairs, while data for the Italian Parliament are form the "Atlante Storico-Elettorale d'Italia”. We measure Turnout as the ratio between the number of voters and the number of eligible voters.

As the Arbëreshë municipalities are a small minority living in very specific areas of Italy, there is a difficulty in finding a clean counterfactual group to compare their behavior to. Our initial starting point is to restrict our attention to regions in which there is at least an Arbëreshë community and to consider only municipalities with less than 8,704 inhabitants (in the 2001 census the largest Arbëreshë municipality has 8703 inhabitants while the remaining Arbëreshë municipalities have on average about 2000 inhabitants). In practice, this restricts our sample to about 961 municipalities, 41 Arbëreshë municipalities (treated group) and 920 indigenous municipalities, located in five different regions (Apulia, Basilicata, Calabria, Molise and Sicily). ${ }^{12}$

\footnotetext{
${ }^{10}$ Unfortunately, data on turnout at the most relevant referenda held in Italy are not available at municipality level. Data on important Italian referenda asking people to express their views on issues such as the legalization of divorce (1974) and abortion (1981) are only available at provincial level and as a result we cannot use them for our analysis. The 2011 referenda were held on national-level issues such as the ownership of local public utility companies and banning the construction of nuclear power plants.

${ }^{11}$ The supranational nature of the European Parliament makes electoral turnout less subject to contamination problems due to patronage.

${ }^{12}$ One may be concerned that there is a degree of arbitrariness in the choice of comparison municipalities. In unreported estimates we adopted a more systematic approach via estimating a propensity score matching model of the probability of a municipality being Arbëreshë. We then used these scores to trim potential comparison municipalities off the common support (i.e. those with a propensity score below the lowest for an actual Arbëreshë village). This was only possible for our estimates of the effect on referenda and European elections turnout; the same technique could not be applied to the general election turnout as appropriate matching variables where not readily available for the whole time period. For these former models, our estimates of interest were qualitatively unchanged.
} 
As shown in Table 1, average turnout in Arbëreshë municipalities is higher than turnout in indigenous municipalities both when considering the 2011 referenda and European elections. Instead, the reverse is true when we look at turnout at general elections.

\section{[TABLE 1]}

To control for municipalities' demographic characteristics, we match each election with the closest Italian Census of Population held every ten years (we use data from 1951 to 2001). ${ }^{13}$ We have information on the size of resident population, the average level of employment, the educational attainment of the population and the percentage of people aged 65 or over. ${ }^{14}$ We use this information to compare Arbëreshë and indigenous municipalities. In Table 2 the mean for the demographic characteristics together with geographic characteristics are reported, both for Arbëreshë and non-Arbëreshë municipalities. In the first three columns we consider the 1951 Italian Census, while in the last three columns we refer to the latest available census, held in 2001 (results do not qualitatively change even when we collapse our data and compare the average values taken in the period 1951-2001 by our variables of interest). Differences in means between Arbëreshë municipalities and non-Arbëreshë municipalities are presented in columns 3 and 6 (standard errors are reported in parentheses). ${ }^{15}$

\section{[TABLE 2]}

Our results show that Arbëreshë and non-Arbëreshë municipalities are comparable in terms of a number of observable characteristics: there are no significant differences between the two groups in terms of employment, average schooling, altitude, size of the territory under the jurisdiction of each municipality. There are, however, some statistically significant differences in terms of population (when considering the 2001 census), the proportion of the population that is older than 65 and the illiteracy rate. Most notably, Arbëreshë municipalities tend to be smaller and to have a higher percentage of elderly and

\footnotetext{
${ }^{13}$ Data from Census 1971, 1981, 1991 and 2001 are accessible through Statistical Atlas of Municipalities (Atlante Statistico dei Comuni) (ISTAT, 2009). There are no readily usable data from Census 1951 and 1961 and we obtained the data by examining the volumes "Censimento della Popolazione" distributed by the Italian Ministry of Internal Affairs in hard copy.

${ }^{14}$ More precisely we use data from the 1951 census for general elections held from 1946 to 1953, data from the 1961 census for general elections held from 1958 to 1963, data from the 1971 census for elections held from 1968 to 1976. Data from the 1981 census are used for general and European elections held in the period 1979-1984. Instead for elections held in the period 1989-1994 we use data from the 1991 census, while data from the 2001 census are used for elections held after 1994.

${ }^{15}$ The difference in the number of observations is due to missing data or to the fact that new municipalities were created from 1951 to 2001.
} 
illiterate people. Our expectation, in terms of our subsequent empirical analysis, is that this difference should lead to, at worst, a conservative (i.e. biased towards zero) estimate of the effect of social capital on behavior. For instance, one would expect lower literacy levels to lead to, if anything, a lower level of voting turnout. While this suggests a lack of observable confounding factors between our villages of interest and comparison villages, unobservable confounding factors may still exist. Even if we cannot directly test this, in our subsequent empirical analysis we take a number of steps aimed at assessing the robustness of our results.

\section{EMPIRICAL METHODOLOGY}

The initial empirical analysis involves estimation of an OLS model with fixed effects at a regional or provincial level $^{16}$ to analyze whether Arbëreshë municipalities display significantly different levels of civic capital compared to similar Italian municipalities. More precisely, we estimate variants of the following model:

$$
\text { Turnout }_{i t}=\beta_{0}+\beta_{1} \text { Arbereshe }_{i}+\beta_{2} X_{i t}+\varphi_{i}+\mu_{t}+\varepsilon_{i t}
$$

where Turnout $_{\text {it }}$ is the outcome variable (voter turnout at referenda, at European elections and at general elections) in municipality $i$ in election year $t ;$ Arbereshe $_{i}$ is our main variable of interest and it takes a value equal to 1 for the 41 villages still maintaining Arbëreshë traits; $X_{i t}$ is a vector of municipal characteristics at the time of elections, such as the population size, the average number of years of education of the inhabitants, the fraction of employed people in the population, the fraction of elderly people; $\varphi_{i}$ and $\mu_{t}$ are respectively region or province (more disaggregated) and an electoral year fixed effect, whereas $\varepsilon_{i t}$ is the stochastic error term of the model.

Arbëreshë villages are a subset of all original villages that were settled or repopulated by the Albanians, and this maintenance of tradition is likely to be non-random. A concern would be that those areas, with unobservable characteristics more likely to lead to different levels of social capital, are also related to differential likelihood of the maintenance of these traditions. For instance, more isolated areas may be less likely to converge to Italian social norms in both terms of observed traditions and voting behavior.

To examine this issue we firstly look at successively more restrictive geographic comparisons. Again the underlying idea is that more proximate areas should differ less in terms of unobserved characteristics

\footnotetext{
${ }^{16}$ Provinces are the lower-tier administrative institution, placed between municipalities (our unit of observation) and regions (such as Apulia, Basilicata, Calabria, Molise and Sicily).
} 
that influence both civic capital and voter turnout. We estimate variants of our model where we successively reduce the comparison group to municipalities within $60 \mathrm{kms}$ and $30 \mathrm{kms}$ of an Arbëreshë municipality.

Finally, we use the historical location of two seminaries that according to researchers gave a great contribution to the preservation of the Arbëreshë culture as a source of variation. This information is at the basis of our 2SLS estimation strategy, specifying the model presented above as follows:

$$
\begin{aligned}
& \text { Turnout }_{i t}=\beta_{0}+\beta_{1} \text { Arbereshe }_{i}+\beta_{2} X_{i t}+\varphi_{i}+\mu_{t}+\varepsilon_{i t} \\
& \text { Arbereshe }_{i}=\alpha_{1} \text { Dist }_{i}+\alpha_{2} \text { Dist }^{2}{ }_{i}+\alpha_{3} X_{i t}+\mu_{t}+v_{i t}
\end{aligned}
$$

From equations [2] and [3] we can notice that Arbereshe $_{i}$ might be positively or negatively correlated with the error term $\varepsilon_{i t}$, leading to biased estimates in the province fixed effects model. For instance, some unobservable features of Arbereshe $_{i}$ municipalities embedded in the error term of equation [1], may affect both the maintenance of Arbëreshë peculiar traits and voters’ decision to cast their vote.

As we only observe the subset of Arbëreshë communities still maintaining some peculiar traits, our instrument relies on the idea (supported for instance by Altimari, 2002, and Cucci, 2007) that cultural resilience has been affected by the closeness to two seminaries, founded to provide free education to the Arbëreshë clergy. Then, we instrument our dummy Arbereshe $_{i}$ with the distance of each municipality to the municipality in which is located the closest seminary. Since the two seminaries are located one in mainland Italy (San Demetrio) and the other on the island of Sicily (Palermo), we consider the distance from the Sicilian seminary for municipalities located in that region and the distance from the one located in the mainland for all the others. ${ }^{17}$ Clearly the initial location choice for the seminaries may not have been random. Nevertheless, their construction occurred in the $18^{\text {th }}$ century and we argue that these location choices were driven by factors that are unlikely to be directly related to current civic behavior. As one may expect the effect of proximity to be non-linear, we introduce a quadratic term in distance. We also alternatively include region or province fixed effects.

\footnotetext{
${ }^{17}$ For the seminar located in Calabria we refer to the San Demetrio location. Nevertheless our estimates do not change much if we alternatively use the initial location of the seminar in San Benedetto Ullano. The distance between San Demetrio and San Benedetto Ullano is $30 \mathrm{Km}$.
} 


\section{OLS RESULTS}

Table 3 provides regional fixed effects estimates of the conditional correlation between Arbëreshë communities and voter turnout. We report results for the 2011 national referenda, the European Parliament elections (1979-2014) and the general elections (1946-2008), respectively. In all regressions standard errors are robust to heteroskedasticity.

For all our turnout measures these reveal a statistically significant relationship. For instance, as shown in column (1), where we only control for regional dummies, referenda turnout is 2.7 percentage points higher in Arbëreshë communities. Since turnout at referenda in indigenous municipalities is on average 53\% this implies an increase in turnout of about $5 \%$.

\section{[TABLE 3]}

As shown in column (3), the corresponding relationship is 3.4 percentage points for turnout at the European elections (on a base of about $66 \%$ this translates in an increase of about 5\%). The relationship between turnout at general elections and Arbëreshë (column 4) shows a similar albeit smaller effect, with a $1 \%$ increase in turnout.

Models reported in columns (2), (4) and (6), introduce controls for a range of potential confounders. These explanatory variables are related to voter turnout in a manner that fits with previous literature and intuition. For instance, the rate of illiteracy is negatively related with turnout, while the share of employed population is positively related with turnout. Introducing these controls substantially improves the 'fit' of these models but does not substantively change the key estimate of interest. ${ }^{18}$ These remain statistically significant for all of our turnout measures.

We control for the average number of years of education of population in estimates for referenda and European-election turnout. This is not included in the general election estimates that cover longer time periods, as it is not readily available for the older censuses.

These relationships are essentially conditional associations and a number of factors exist that may prevent them from being treated causally. There may, for instance, be variations in unobservable characteristics between Arbëreshë and non-Arbëreshë communities that may be correlated with turnout behavior and civic capital in general. Our first attempt to address this is to restrict the level of comparison by introducing province-level fixed effects to our estimates. In this way we seek to wash out unobservable factors influencing turnout behavior that relate to specific areas of Italy. The resultant estimates of the models including the full set of controls are provided in Table 4.

\footnotetext{
${ }^{18}$ These results do not change qualitatively also when we control for the average income per capita in each municipality and for a poverty index (only available starting form 2009). These results are not reported and available upon request.
} 
Our key estimate now can be interpreted as the within province variation in turnout behavior associated with a community being Arbëreshë. As shown in columns (1), (2) and (3) for turnout at referenda, European and general elections respectively, while there is some movement in the point estimates, there remains a positive and statistically significant relationship between Arbëreshë communities and voter turnout behavior. The magnitude of the effects is similar, slightly smaller, to that found when controlling for regional dummies.

\section{[TABLE 4]}

As an alternative approach to within-province estimation we also looked at successively more restrictive geographic comparisons. Again the underlying idea is that more proximate areas should differ less in terms of unobserved characteristics that influence both civic capital and voter turnout. Here, we use provincial fixed effects and estimate variants of our models from Table 4, including the full set of controls (not reported to save space), where we successively reduce the comparison group to municipalities within $60 \mathrm{kms}$ and $30 \mathrm{kms}$ of an Arbëreshë municipality. ${ }^{19}$ These estimates are reported in Table 5. These reveal that our initial results remain in essence even in the most narrow geographic comparison group.

Taken together this is supportive of a causal difference insofar as neighboring municipalities, controlling for observed differences, differ markedly in their turnout behavior on the basis of their ethnic composition. This evidence is suggestive of differences of behavior that reflect higher levels of civic capital within Arbëreshë municipalities.

\section{[TABLE 5]}

Having established a contemporaneous relationship between Arbëreshë communities and our indicator of civic capital, a natural question is whether this difference in behavior represents a diminished differential compared to, for instance, larger differences from the native population upon initial immigration. In this sense, we are interested in whether there is an indication of assimilation of immigrant behavior towards the norms of the recipient country. To investigate this we use the general election turnout data to examine behavior across the post-war period. While this is not the same as examining changes in behavior since the $17^{\text {th }}$ century, it provides indicative evidence insofar as the post-war period represents one of increased geographic and social mobility. Specifically, we introduce a linear time trend, $t$, and an

\footnotetext{
19 The National Statistical Office (ISTAT) provides the geo-coding of all the Town Halls of the 8101 Italian municipalities. Through these data, for each municipality the “crow’s flight” distance with each of the Arbëreshë municipalities is calculated. If the minimum of these distances is larger than the threshold, the municipality is discarded from the analysis.
} 
interaction term between the dummy denoting Arbëreshë municipalities and the time trend, Arbereshe*t, among the regressors.

As shown in column (7) and (8) there is a general decline in turnout over the period of approximately 0.3 of a percentage point per year (we observe 18 elections in our data period). The interaction term between Arbëreshë municipalities and year, while negative, is not statistically significant at standard levels. This suggests that at best there is weak evidence of convergence of Arbëreshë and non- Arbëreshë behavior over the post-war periods. We contend that this, in addition to earlier estimates, is a powerful result insofar as it demonstrates the ability of different civil capital to persist even during a period of increasing mobility and interaction.

\section{Instrumental Variable Results}

Despite our attempts to investigate the sensitivity of our results to appropriate comparison areas, we cannot rule out that our results are driven by underlying differences in unobservable characteristics. As explained above, a particular concern is that we are measuring the effect of ex post being an Arbëreshë community. This is a concern as this is a subset of areas where initial settlement occurred and the maintenance of tradition is likely to be non-random. Most critically, those areas where differences in underlying civic capital were greatest may be those municipalities where we might expect these communities to survive as recognizably distinct groups. We seek to directly examine this source of bias using an instrumental variable approach that exploits exogenous variation in the likelihood of maintaining traditions.

Table 6 provides the IV estimates that correspond to equations (2) and (3). Panel B of the Table provides the first stage estimates. These reveal a strong negative relationship between distance to a seminary location and being an Arbëreshë community. The square term is positive, and the turning point is at the most distant quartile of the distribution (the turning point is between 130 and $180 \mathrm{~km}$ according to specifications). Our instruments pass standard tests for weak instruments. The value of $\chi_{2}$ in all specifications is well above the standard thresholds.

Panel A of Table 6 reports second stage estimates for region and province fixed effects models controlling for the full set of controls. In the specifications including province fixed effects only municipalities located in provinces in which there is at least one Arbëreshë community are included in the sample (being included in a province in which Arbëreshë are absent perfectly predicts the outcome variable and is dropped from our probit estimates). In all specifications standard errors are bootstrapped (100 replications).

In both the regional and province fixed effects models, the IV estimates are positive and statistically significant. The magnitude of the difference in turnout behavior between Arbëreshë and indigenous 
municipalities is larger in regional fixed effects estimates than in province fixed effects estimates. In all cases we find that the instrumental variables estimates are larger in size compared to OLS estimates. For instance, as shown in column (2), when controlling for province fixed effects, referenda turnout is 11.7 percentage points higher in Arbëreshë communities (which on a base of 53\% implies an increase of about 22\%). The corresponding effect is 5.6 percentage points for general elections (column 6), which implies a 7\% increase. Instead, in the case of turnout at European elections this estimate is particularly large: 17 percentage points.

Together, these results suggest that our earlier estimates are not being driven by non-random maintenance of traditions.

\section{[TABLE 6]}

\section{EXTENSIONS}

To this point we have demonstrated a robust relationship between Arbëreshë communities and voting behavior. We next perform some additional robustness checks and explore a range of extensions aimed primarily at demonstrating whether this is likely to be due to pro-social behavior more generally and the extent to which this is specific to these communities.

Arbëreshë enclaves have not been totally segregated from the rest of Italy since settlement. For instance, mixed marriages and in-migration may have led to a potential dilution of local attitudes. ${ }^{20}$ However, as the villages we examine are located in a very poor area in-migration is a relatively negligible phenomenon. In addition, as shown by Resta (1991), until recently, differences in ethnicity and language represented barriers that impeded inter-marriage between the two groups. ${ }^{21}$ Only in the 1960s and 1970s, with the improvement in regional infrastructure, work-related migration to central Europe and northern Italy and the diffusion of educational programs, have marital exchanges converged to rates observed in the surrounding populations. In the current setting, non-Arbëreshë immigrants reside in Arbëreshë villages, especially individuals who married Arbëreshë men and women. Unfortunately, there is no accurate information that allows us to distinguish between non-Arbëreshë and Arbëreshë individuals living in ItaloAlbanian villages. ${ }^{22}$ As an alternative to official records we contacted the Mayoral office of each of the 41 villages and asked (in his/her opinion) what proportion of inhabitants continued to speak the Arbërisht

\footnotetext{
${ }^{20}$ Migration out of these villages is not a source of bias unless it was selective based on pro-civic attitudes. In case of migration in surrounding villages we would expect a down-ward bias in our estimates.

${ }^{21}$ For instance, Fiorini et al. (2007), using marriage records, show that different ethnicity was the dominant constraint to marital exchanges among the Arbëreshë during the 1800s and during the first three decades of the 20th century.

${ }^{22}$ Similarly, it is not possible to count the Arbëreshë that emigrated to the North of Italy or abroad, as they are "hidden" in the general population of the places where they have settled.
} 
language. ${ }^{23}$ This proportion, that we name Arbereshe Intensity, ranges from $0 \%$ to $100 \%$ with a mean value of $64 \%$. We then use this information in place of our Arbëreshë indicator variable and re-estimate our main fixed effects models of voter turnout. This is reported in Table 7, Panel A. This reveals that turnout behavior is increasing in the proportion of the population who speak Arbërisht. ${ }^{24}$ For instance, when looking at turnout at the referenda we find that in villages with $50 \%$ of the population speaking Arbërisht turnout is about 1.85 percentage points higher compared to villages in which nobody speaks that language. Similar magnitude effects are apparent with respect to turnout at European elections.

\section{[TABLE 7]}

Voting behavior is just one potential measure of pro-social behavior. Many of the standard candidates for proxies for social capital (e.g. blood donations) are not available at a suitable level of geographical disaggregation. However, we are able to construct a measure of tax evasion at the municipality level. We do this by focus on a very specific form of taxation, the payment of the television license tax, that is available at a municipality level. This data is advantageous as it is a relatively small tax (112 Euros p.a.) with essentially no exemptions. ${ }^{25}$ If a household owns a TV set, they are required to purchase a license. It is also very weakly enforced, easy to evade and typical fines for a household are low relative to cost (up to 516 Euros plus a mandatory 5 year license purchase). As a result approximately one third of households do not purchase a licence. ${ }^{26}$ Taken together, this makes it an opportune instrument for assessing social attitudes to taxation.

The dependent variable Compliance is constructed by dividing the number of TV licenses issued in a municipality by the number of households in the same municipality. This implies that in absence of measurement error and in case of full compliance the variable takes value 1, while the smaller the value of this variable (i.e. the fewer the households per TV license) the higher the evasion rate.

\section{[TABLE 8]}

Table 8 reports variants of our earlier main models where the dependent variable is the TV License Compliance Rate. In columns 1-3 we show the results of the OLS regression with different locality fixed

\footnotetext{
${ }^{23}$ We wrote an e-mail asking the following question: According to your opinion which is the fraction of the population in your village still speaking the Arbërist language? Respondents could select: 1) Only few; 2) Less than $20 \%$ of the population; 3) $30 \%-40 \%$ of the population; 4) About $50 \%$ of the population; 6) About $60 \%$ of the population; 7) About 70\% of the population; 8) About $80 \%$ of the population; 9) About 90\% of the population; 10) About $100 \%$ of the population. In the case that mayors did not reply to our e-mail, we contacted them by phone.

${ }^{24}$ In unreported estimates, tax compliance is also increasing in Arbëreshë intensity.

${ }^{25}$ Household including only people over 75 years old with a (household) gross income under Euro 6,713.98, foreign diplomatic personnel, and NATO military forces are the only exempted subjects.

${ }^{26}$ In 2010, 67.5\% of households held a TV licence (16,654,612 licences were issued by RAI TV, as opposed to 24,641,200 households reported by the latest National Statistical Office ISTAT figure). The ISTAT “Aspects of Daily Life” survey for 2010 (“Aspetti della Vita Quotidiana”) mentions that 96\% of households states to own a TV set.
} 
effects (resp. no fixed effects, regional and provincial), while in columns 4 we show the results of our IV approach (again with regional and then provincial fixed effects). Importantly, the pattern of results largely follows those reported for our turnout measures in Tables 3-6, albeit with some loss in precision. The OLS regressions show that Arbëreshë communities have a higher compliance rate, but one that is of a small magnitude. The IV estimates suggests larger, substantive, effects in the order of 10 percentage point higher compliance rates. Qualitatively very similar results are found when we consider as independent variable Arbereshe Intensity (results not reported and available upon request). Nonetheless, these results are supportive of the view that our earlier findings reflect more broad differences in behavior, rather than being related purely to voting and political involvement.

Nevertheless still we are left with a question of the channel of effect. Why do these populations behave better in terms of social capital? One candidate is that these villages simply have more homogenous populations and this is associated with better civic behavior (see for instance Alesina and La Ferrara, 2000; Hardin, 1993, Misztal, 1995). While we cannot rule this out this seems an unlikely source given our comparison group drawn from proximate villages. These areas, are poor and characterized by low in and out migration, and ethnically homogenous. Along these lines, we examined data from the Bilancio Demografico Italiano, released by the Italian National Institute of Statistics. These demonstrated that that in-migration and out-migration in Arbëreshë and non Arbëreshë villages are very similar, and very low (up to $2 \%$ p.a.).

We further examined this point by exploiting the existence of ethnically homogenous Greek enclaves (who speak a Greek dialect) in the south of Italy. These Greek speaking enclaves are located in Apulia ${ }^{27}$ (Griko) and Calabria ${ }^{28}$ (Grecanico). There is some contention regarding the origin of these enclaves with respect to whether they reflect settlement during the Byzantine Empire (330 A.D. to 1453 A.D.) or are the continuation of settlement from Ancient Greece started during Classical Hellenic period (circa $8^{\text {th }}$ century B.C.). ${ }^{29}$ Similarly to the Arbëreshë these communities are homogenous due differences in language and ethnicity that restricted inter-marriage with the surrounding populations. ${ }^{30}$ To investigate the behavior of these enclaves, we include a dummy variable for these municipalities in our main fixed effects models. Estimates are reported in Table 7, Panel B. While the Arbëreshë coefficient remains positive and greater than zero, the coefficient for the Greek municipalities is essentially zero. While not definitive, this placebo

\footnotetext{
${ }^{27}$ In the villages: Calimera, Castrignano dei Greci, Corigliano di Otranto, Martano, Martignano, Melpignano, Soleto, Sternatia, and Zollino (see, Profili, 1985).

${ }^{28}$ In the villages: Amendolea, Bagaladi, Brancaleone, Bova, Bova Marina, Condofuri, Gallicianò, Melito, Roghudi, Roccaforte del Greco, San Lorenzo, Staiti (see, Katsoyannou, 2001 and Viola 1997).

${ }^{29}$ Morosi, 1870; Rohlfs 1966, 1972

${ }^{30}$ It must be noted though that in these comunities the orthodox rite was abandoned since the Norman domination (1000 A.D). See Loude and Metcalfe, 2002.
} 
tests suggests that it is no purely homogeneity causing the observed differences in behavior between the Arbëreshë and proximate communities.

A further channel that could drive our results is the retention of the orthodox religion. The previous literature on the relationship between religion and social capital (measured for instance in terms of trust) find that Catholics show significantly less trust than Protestants (Uslaner, 2000) and that hierarchical religions produce a negative effect on trust (La Porta et al., 1997; Berggren and Jordahl, 2006).

The impact produced by the orthodox religion on social capital is less explored also because orthodox countries are often also ex-communist countries. We exploit the fact that approximately half of our Arbëreshë communities no longer formally observe the Orthodox rites. During the Counter Reformation (beginning with the Council of Trent (1545-1563) and ending a century later) the Catholic Church tried to impose their own rites with some successful results depending also on the availability of Orthodox priests (Altimari and Savoria, 1994). Today villages maintaining the orthodox rite belong to two Eparchies (to Lungro for Arbëreshë in continental Italy, and that of Piana degli Albanesi for the Arbëreshë of Sicily). We use this information to split our Arbëreshë indicator based on this observance. These results are reported in Table 7, Panel C. Two things are worth noting. First, generally both sets of estimates are positive. All Arbëreshë communities exhibit higher turnout. There is, however, some indication that the orthodox communities have the highest turnout, but the two sets of estimates are never statistically different from each other at standard levels. Insofar as the retention of the orthodox religion proxies maintenance of Arbëreshë conditions, this provides suggestive evidence that the differences in behavior we estimate are driven by underlying ethnic attitudinal differences.

\section{CONCLUSIONS}

There is an increasing body of research, which seeks to understand the extent to which differences in social, and particularly civic capital lead to differences in economic and social behavior. This paper adds to this literature focusing on a unique historical immigration event in Italy in the $16^{\text {th }}$ century. This is of interest insofar as it represents the mass settlement of a group with markedly different traditions into an established society.

Focusing on an established measure of civic capital, voter turnout, our initial results suggest that despite the long time since this event these communities still display different, higher, civic capital than other comparable Italian communities. This survives a number of robustness checks including focusing on very small geographic points of comparison and instrumental variable estimation aimed at addressing the non-random maintenance of traditions. We also demonstrate that our results extend to other proxies of social capital such as tax compliance and that they cannot be explained solely in terms of population homogeneity or retention of the orthodox religion. 
We are not able to demonstrate whether these immigrants were characterized by pre-immigration differences in social capital or whether an attitude toward cooperation and trust has developed as a consequence of the facts following their immigration. Nevertheless we think our analysis is important to document long-term persistence in differences in social capital. A point of novelty from previous literature is to consider how this variation in behavior has evolved over the past 60 years. This is motivated by the belief that initial differences in attitudes and behavior are likely to be eroded over time, especially in recent decades when regional mobility and the general level of regional interaction has increased. We find no evidence that there has been a change in the difference in civic capital between our communities of interest and Italian communities. Specifically, the difference in voter turnout apparent in the late 1940's, early 1950's remains in the $21^{\text {st }}$ century. This finding has implications for our view of the likelihood of assimilation of immigrant groups, particularly in cases of large scale migration. 


\section{REFERENCES}

Alesina A., La Ferrara E., 2000. Participation in Heterogeneous Communities. Quarterly Journal of Economics 115(3), pp. 847-904.

Altimari F., 2002. La minoranza Arbëreshë: profilo storico-culturale. In: Belluscio G., Lentini V. (Eds.) La minoranza linguistica italo-albanese. Aspetti educativi e culturali, Catanzaro: IRRE Calabria, pp. 1338.

Altimari F., Savoia, L.M., 1994. I dialetti italo-albanesi. Studi linguistici e storico-culturali sulle comunità arbëreshe, Roma: Bulzoni Editore.

Amodio F., 2012. Hard to Forget: Long Lasting Effects of Social Capital Accumulation Shocks. mimeo.

Argondizza, A., 1961. Gli italo-albanesi e il Risorgimento Italiano. Cronache di Calabria LIX, 35(4).

Barone G., Mocetti, S., 2014. Inequality and trust: new evidence from panel data. Temi di discussione (Economic working papers) 973, Bank of Italy, Rome.

Bertoni, M., Brunello, G., Rocco, L., 2013. When the cat is near, the mice won't play: The effect of external examiners in Italian schools. Journal of Public Economics 104, pp. 65-77.

Beugelsdijk, S., de Groot, H., van Schaik, A., 2004. Trust and economic growth: a robustness analysis. Oxford Economic Papers 56, 118-134.

Bugliaro, S. (Ed.), 2002, Gli Arbëresh di Calabria, Rossano: Grafosud.

Buonanno, P., Montolio, D., Vanin, P., 2009. Does social capital reduce crime? Journal of Law and Economics 52.1, pp. 145-170.

Cucci F., 2007. Gli Istituti di Cultura Arbëreshë, $\underline{\text { www.centrointernazionalestudisulmito.com/ebooks/albanesi.pdf }}$

Derhemi, E., 2002. The endangered Arbresh language and the importance of standardised writing for its survival: the case of Piana degli Albanesi, Sicily. Journal on Multicultural Societies 4(2), pp.1-33.

Costa D. L., Kahn, M.E., 2003. Understanding the American Decline in Social Capital, 1952--1998. Kyklos 56(1), pp. 17-46.

Di Pasquale, D., Glaeser, E.L., 1999. Incentives and Social Capital: Are Homeowners Better Citizens? Journal of Urban Economics 45(2), pp. 354-384.

Durante, R., 2010. Risk, Cooperation, and the Economic Origins of Social Trust: an Empirical Investigation, Unpublished, Sciences Po.

Fiorini, S., Tagarelli G., Boattini A., Luiselli D., Piro A., Tagarelli A, Pettener D., 2007. Ethnicity and Evolution of the Biodemographic Structure of Arbereshe and Italian Populations of the Pollino Area, southern Italy (1820-1984). American Anthropologist 109(4), pp.735-746.

Freire T., Li X., 2013. How Immigration Reduced Social Capital in the US: 2005-2011. MPRA Paper No. 44540. 
Glaeser E.L., Laibson D., Sacerdote B., 2002. An Economic Approach to Social Capital, Economic Journal 112(483), pp.437-458.

Guiso, L., Sapienza, P., Zingales, L., 2004. The Role of Social Capital in Financial Development, American Economic Review 94 (3), 526-556.

Guiso, L., Sapienza, P., Zingales, L., 2008. Social Capital and Good Culture, Marshall Lecture, Journal of the European Economics Association 6(23), 295-320.

Guiso, L., Sapienza, P., Zingales, L., 2010. Civic Capital as the Missing Link, NBER Working Paper, No. 15845.

Hardin, R., 1993. The Street-Level Epistemology of Trust. Politics and Society 21:505-29.

Helliwell, J. F., Putnam R. D., 1995. Economic growth and social capital in Italy. Eastern Economic Journal 21.3: 295-307.

Loud G.A., Metcalfe, A. (Eds.), 2002. The Society of Norman Italy. Leiden: Koninklijke Brill.

Jacob, M., Tyrell, M., 2010. The Legacy of Surveillance: An Explanation for Social Capital Erosion and the Persistent Economic Disparity Between East and West Germany. mimeo.

Katsoyannou, M., 2001. Le parler grec de Calabre: Situation linguistique et sociolinguistique. LALIES

21: 7-59.

Knack, S., 2002. Social Capital and the Quality of Government: Evidence from the States. American Journal of Political Science 46(4), 772-785.

Knack, S. Keefer, P., 1997. Does social capital have an economic payoff? A cross-country investigation. The Quarterly journal of economics 112(4), 1251-1288.

La Porta, R., Lopez-de-Silanes, F., Shleifer, A., Vishny, R.W., 1997. Trust in large organizations. American Economic Review, 87, 333-338.

Misztal, B., 1995. Trust in Modern Societies. Cambridge: Polity Press.

Morosi, G., 1870. Studi Sui Dialetti Greci Della Terra D'Otranto. Lecce: Editrice Salentina.

Nasse G.N., 1964. The Italo Albanian Villages of Southern Italy. Washington, D.C.: National Academy of Sciences National Research Council.

Newton, K., 1997., Social Capital and Democracy. American Behavioral Scientist 40: 575-586.

Nunn, N., Wantchekon, L., 2011. The Slave Trade and the Origins of Mistrust in Africa. American Economic Review 101: 3221-3252.

Paccagnella, M., Paolo S., 2014. School cheating and social capital. Education Economics 22, pp. 367388.

Putnam, R., 1995. Bowling Alone: America's Declining Social Capital. Journal of Democracy 6(1): 65-78. 
Putnam, R. Leonardo, R., Nanetti, R., 1993. Making Democracy Work: Civic Traditions in Modern Italy, Princeton: Princeton University Press.

Pedio, T., 1943. Contributo alla storia delle immigrazioni albanesi nel Mezzogiorno d'Italia. Firenze: Accademia d'Italia, Centro di studi per l'Albania 4(3).

Prato, G.B., 2009. Minorities in Italy: The Case of Arberesh and Albanian Migration. In: Prato, G.B. (Eds.), Beyond Multiculturalism. Views from Antropology. Urban Anthropology Series, Ashgate.

Profili, O., 1985. La romanisation d'un parler grec de l'Italie du Sud par les parlers romans environants, Actes du XVIIe Congres International de Linguistique et de Philologie Romanes, Aix-en-Provence, Université de Provence, pp. 129-139.

Resta, P., 1991. Parentela ed Identità Etnica: Consanguineità e Scambi Matrimoniali in Una Comunità Italo-Albanese (Kinship and ethnic idenity: Inbreeding and marital exchanges in a Italo-Albanian community). Milano: FrancoAngeli.

Rohlfs, G., 1966. Grammatica storica della lingua italiana e dei suoi dialetti: fonetica. Torino: Einaudi.

Rohlfs, G., 1972. Nuovi scavi linguistici nella antica Magna Grecia. Palermo: Luxograph.

Scaglione, P., 1921. Storia degli Albanesi d'Italia, New York.

Seligson, A.L., 1999. Civic association and democratic participation in Central America: a test of the Putnam thesis. Comparative Political Studies 32, 342-62.

Serra, A., 1947. I profughi d'Albania verso l'Italia ospitale. Ricerche storiche sulle migrazioni albanesi in Italia nei sec. XIV-XVIII. Castrovillari.

Tabellini, G., 2008. The Scope of Cooperation: Normes and Incentives. Quarterly Journal of Economics $123(3), 905-950$.

Tabellini, G., 2010. Culture and Institutions: Economic Development in the Region of Europe. Journal of the European Economic Association 8 (4), 677-716.

Uslaner, E.M., 1999. Democracy and social capital. In: Warren, M. (Ed.), Democracy and Trust. Cambridge, UK: Cambridge University Press.

Uslaner, E.M., 2002. The Moral Foundations of Trust. New York: Cambridge University Press.

Voigtländer N., Satyanath, S., Voth, H., 2014. Bowling for Fascism: Social Capital and the Rise of the Nazi Party. NBER Working paper n.19201.

Voigtländer N., Voth, H., 2014. Highway to Hitler. NBER Working paper n. 20150.

Violi F., 1997. La grecità calabrese: origini e storia. Bova (Reggio Calabria): Apodiafàzzi.

Zangari, D., 1940. Le Colonie Italo-Albanesi di Calabria, Storia e Demografia Secoli XV -XIX. Napoli: Caselli. 
Zak, P.J., Knack, S., 2001. Trust and growth, Economic Journal 111:295-321. 
Table 1. Turnout across Arbëreshë and Indigenous Municipalities

\begin{tabular}{lccc}
\hline \hline & Autochthons & Arbëreshë & Observations \\
& Municipalities & Municipalities & \\
\hline Turnout Referenda & 0.5287 & 0.5466 & 961 \\
& $(0.0809)$ & $(0.0641)$ & \\
Turnout European Election & 0.6585 & 0.6837 & 7712 \\
& $(0.1411)$ & $(0.1137)$ & \\
Turnout General Elections & 0.7917 & 0.7886 & 16717 \\
& $(0.1193)$ & $(0.1242)$ & \\
\hline \hline
\end{tabular}

Table 2. Demographic and Geographic Characteristics across Arbëreshë and Indigenous Municipalities

\begin{tabular}{|c|c|c|c|c|c|c|}
\hline & \multicolumn{2}{|c|}{$\begin{array}{c}1951 \text { Census } \\
\text { Mean }\end{array}$} & \multirow{2}{*}{$\begin{array}{c}\text { Difference } \\
(3)\end{array}$} & \multicolumn{2}{|c|}{$\begin{array}{c}2001 \text { Census } \\
\text { Mean }\end{array}$} & \multirow{2}{*}{$\begin{array}{c}\text { Difference } \\
(6)\end{array}$} \\
\hline & (1) & $(2)$ & & (4) & (5) & \\
\hline & $\begin{array}{c}\text { Autochthons } \\
\text { Municipalities } \\
\text { pop }<8,704\end{array}$ & $\begin{array}{c}\text { Arbereshe } \\
\text { Municipalities } \\
\text { pop }<8,704 \\
\end{array}$ & & $\begin{array}{c}\text { Autochthons } \\
\text { Municipalities } \\
\text { pop<8,704 }\end{array}$ & $\begin{array}{c}\text { Arbereshe } \\
\text { Municipalities } \\
\text { pop<8,704 }\end{array}$ & \\
\hline Population & $\begin{array}{c}3450.142 \\
(2085.411)\end{array}$ & $\begin{array}{c}3126.154 \\
(1502.319)\end{array}$ & $\begin{array}{c}-323.9882 \\
(337.686)\end{array}$ & $\begin{array}{c}3083.960 \\
(2080.927)\end{array}$ & $\begin{array}{c}2038.450 \\
(1545.356)\end{array}$ & $\begin{array}{c}1045.510 * * * \\
(253.780)\end{array}$ \\
\hline Employment/Population & $\begin{array}{c}0.142 \\
(0.068)\end{array}$ & $\begin{array}{c}0.141 \\
(0.032)\end{array}$ & $\begin{array}{c}0.015 \\
(0.013)\end{array}$ & $\begin{array}{c}0.270 \\
(0.039)\end{array}$ & $\begin{array}{c}0.270 \\
(0.034)\end{array}$ & $\begin{array}{c}0.000 \\
(0.005)\end{array}$ \\
\hline Years of Education & $\begin{array}{c}7.119 \\
(0.614)\end{array}$ & $\begin{array}{c}7.140 \\
(0.466)\end{array}$ & $\begin{array}{c}0.021 \\
(0.099)\end{array}$ & $\begin{array}{c}7.097 \\
(0.602)\end{array}$ & $\begin{array}{c}7.132 \\
(0.475)\end{array}$ & $\begin{array}{l}-0.035 \\
(0.077)\end{array}$ \\
\hline Illiteracy Rate (\%) & $\begin{array}{c}0.042 \\
(0.025)\end{array}$ & $\begin{array}{c}0.057 \\
(0.030)\end{array}$ & $\begin{array}{c}-0.012^{* * *} \\
(0.009)\end{array}$ & $\begin{array}{c}0.047 \\
(0.027)\end{array}$ & $\begin{array}{c}0.059 \\
(0.032)\end{array}$ & $\begin{array}{c}-0.012 * * * \\
(0.005)\end{array}$ \\
\hline Elderly people (over 65) & $\begin{array}{l}0.220 \\
(0.058)\end{array}$ & $\begin{array}{c}0.241 \\
(0.053)\end{array}$ & $\begin{array}{c}-0.021^{* * *} \\
(0.009)\end{array}$ & $\begin{array}{c}0.218 \\
(0.055)\end{array}$ & $\begin{array}{c}0.244 \\
(0.055)\end{array}$ & $\begin{array}{c}-0.026 * * * \\
(0.009)\end{array}$ \\
\hline Altitude & $\begin{array}{c}461.594 \\
(267.581) \\
267.5807\end{array}$ & $\begin{array}{c}491.128 \\
(184.030)\end{array}$ & $\begin{array}{l}-29.534 \\
(43.289)\end{array}$ & $\begin{array}{c}445.533 \\
(262.157)\end{array}$ & $\begin{array}{c}498.900 \\
(188.053)\end{array}$ & $\begin{array}{l}-53.367 \\
(30.963)\end{array}$ \\
\hline Area size (squared-km) & $\begin{array}{c}40.456 \\
(36.512)\end{array}$ & $\begin{array}{l}35.399 \\
28.027\end{array}$ & $\begin{array}{l}-5.057 \\
(5.920)\end{array}$ & $\begin{array}{c}41.162 \\
\text { (38.222). }\end{array}$ & $\begin{array}{c}31.700 \\
(23.456)\end{array}$ & $\begin{array}{c}9.462 \\
(3.917)\end{array}$ \\
\hline Observations & 915 & 40 & & 920 & 41 & \\
\hline
\end{tabular}

Notes: Standard errors are reported in parentheses. In the last column we report the $p$-value for a test of equality of variable means across all three groups. 
Table 3. Regional fixed effects estimates. Voter Turnout and Arbëreshë communities

\begin{tabular}{|c|c|c|c|c|c|c|}
\hline & \multicolumn{2}{|c|}{$\begin{array}{l}\text { Referenda } \\
\text { (2011) }\end{array}$} & \multicolumn{2}{|c|}{$\begin{array}{c}\text { European Elections } \\
(1979-2014) \\
\end{array}$} & \multicolumn{2}{|c|}{$\begin{array}{c}\text { General Elections } \\
\text { (1946-2008) }\end{array}$} \\
\hline & (1) & $(2)$ & (3) & (4) & (5) & (6) \\
\hline \multirow[t]{2}{*}{ Arbëreshë } & $0.0275^{* * *}$ & $0.0243^{* * *}$ & $0.0336 * *$ & $0.0351^{* * *}$ & $0.0107 * * *$ & $0.0115^{* * *}$ \\
\hline & $(0.00903)$ & $(0.00839)$ & $(0.0131)$ & $(0.0125)$ & $(0.00336)$ & $(0.00335)$ \\
\hline \multirow[t]{2}{*}{ Population } & & 0.00451 & & $0.0174 * * *$ & & $0.0132 * * *$ \\
\hline & & $(0.00498)$ & & $(0.00573)$ & & $(0.00155)$ \\
\hline \multirow[t]{2}{*}{ Population sq. } & & -0.000584 & & $-0.00201^{* * *}$ & & $-1.38 \mathrm{e}-09 * * *$ \\
\hline & & $(0.000556)$ & & (0.000630) & & $(1.82 \mathrm{e}-10)$ \\
\hline \multirow[t]{2}{*}{ Illteracy Rate (\%) } & & -0.00654 & & $-0.235^{*}$ & & $-0.0545 * * *$ \\
\hline & & $(0.0975)$ & & (0.139) & & $(0.00677)$ \\
\hline \multirow[t]{2}{*}{ Employed } & & 0.0170 & & $0.344 * * *$ & & $0.0487 * * *$ \\
\hline & & $(0.0569)$ & & $(0.0680)$ & & $(0.00591)$ \\
\hline \multirow[t]{2}{*}{ Education } & & $0.0586^{* * *}$ & & $0.0298 * * *$ & & \\
\hline & & $(0.00803)$ & & $(0.00730)$ & & \\
\hline \multirow[t]{2}{*}{ Altitude (1000m) } & & $0.0549 * * *$ & & -0.00778 & & $-0.0427 * * *$ \\
\hline & & $(0.0127)$ & & $(0.0148)$ & & $(0.00350)$ \\
\hline \multirow[t]{2}{*}{ Area (sq. km) } & & -0.0000911 & & -0.00000910 & & -0.00000389 \\
\hline & & $(0.0000683)$ & & $(0.0000819)$ & & $(0.0000208)$ \\
\hline \multirow[t]{2}{*}{ Constant } & $0.506^{* * *}$ & $0.186 * * *$ & $0.768 * * *$ & $0.531 * * *$ & $0.914^{* * *}$ & $0.907 * * *$ \\
\hline & $(0.00617)$ & $(0.0496)$ & $(0.00702)$ & $(0.0495)$ & $(0.00227)$ & $(0.00488)$ \\
\hline Locality FE & reg & reg & reg & reg & reg & reg \\
\hline Time FE & no & no & legislature & legislature & legislature & legislature \\
\hline $\mathrm{N}$ & 971 & 971 & 7712 & 7712 & 16574 & 16539 \\
\hline r2 & 0.102 & 0.206 & 0.237 & 0.281 & 0.434 & 0.448 \\
\hline
\end{tabular}

Notes: The dependent variable is voter turnout, as measured by the number of voters on the number of individuals eligible to vote. We control for regional fixed effects and for electoral year dummies (not reported) in all the regressions were turnout is observed for more than one year. Standard errors (corrected for heteroskedasticity and clustered at the municipality level) are reported in parenthesis. The symbols $* * *, * *, *$ indicate that coefficients are statistically significant respectively at the 1,5 , and 10 percent level. 
Table 4. Province fixed effects estimates. Voter Turnout and Arbëreshë communities

\begin{tabular}{|c|c|c|c|c|c|c|}
\hline & \multicolumn{2}{|c|}{$\begin{array}{c}\text { Referenda } \\
\text { (2011) }\end{array}$} & \multicolumn{2}{|c|}{$\begin{array}{c}\text { European Elections } \\
(1979-2014) \\
\end{array}$} & \multicolumn{2}{|c|}{$\begin{array}{c}\text { General Elections } \\
(1946-2008)\end{array}$} \\
\hline & $(1)$ & $(2)$ & (3) & (4) & (5) & (6) \\
\hline \multirow[t]{2}{*}{ Arbëreshë } & $0.0257 * * *$ & $0.0235^{* * *}$ & $0.0237 * * *$ & $0.0264 * * *$ & $0.00778 * *$ & $0.00903^{* * *}$ \\
\hline & $(0.00971)$ & $(0.00904)$ & $(0.00618)$ & $(0.00611)$ & $(0.00342)$ & $(0.00337)$ \\
\hline \multirow[t]{2}{*}{ Population } & & 0.00215 & & $0.0158^{* * *}$ & & $0.0142 * * *$ \\
\hline & & $(0.00473)$ & & $(0.00278)$ & & $(0.00151)$ \\
\hline \multirow[t]{2}{*}{ Population sq. } & & -0.000542 & & $-0.00204^{* * *}$ & & $-1.51 \mathrm{e}-09 * * *$ \\
\hline & & $(0.000519)$ & & $(0.000311)$ & & $(1.77 \mathrm{e}-10)$ \\
\hline \multirow[t]{2}{*}{ Illteracy Rate (\%) } & & 0.0189 & & $-0.235 * * *$ & & $-0.0497 * * *$ \\
\hline & & $(0.101)$ & & $(0.0670)$ & & $(0.00679)$ \\
\hline \multirow[t]{2}{*}{ Employed } & & 0.0479 & & $0.233^{* * *}$ & & $0.0334^{* * *}$ \\
\hline & & $(0.0607)$ & & $(0.0403)$ & & $(0.00590)$ \\
\hline \multirow[t]{2}{*}{ Education } & & $0.0644 * * *$ & & $0.0276^{* * *}$ & & \\
\hline & & $(0.00844)$ & & $(0.00379)$ & & \\
\hline \multirow[t]{2}{*}{ Altitude (1000m) } & & $0.0581 * * *$ & & -0.00689 & & $-0.0351 * * *$ \\
\hline & & $(0.0132)$ & & $(0.00710)$ & & $(0.00356)$ \\
\hline \multirow[t]{2}{*}{ Area (sq. km) } & & 0.0000444 & & $0.000127 * * *$ & & $0.0000609 * * *$ \\
\hline & & $(0.0000637)$ & & $(0.0000450)$ & & $(0.0000226)$ \\
\hline \multirow[t]{2}{*}{ Constant } & $0.620 * * *$ & $0.279 * * *$ & $0.663^{* * *}$ & $0.471^{* * *}$ & $0.857 * * *$ & $0.846^{* * *}$ \\
\hline & $(0.0170)$ & $(0.0528)$ & $(0.00863)$ & $(0.0248)$ & $(0.00306)$ & $(0.00556)$ \\
\hline Locality FE & prov & prov & prov & prov & prov & prov \\
\hline Time FE & no & no & legislature & legislature & legislature & legislature \\
\hline $\mathrm{N}$ & 971 & 971 & 7712 & 7712 & 16574 & 16539 \\
\hline $\mathrm{r} 2$ & 0.185 & 0.300 & 0.291 & 0.322 & 0.463 & 0.474 \\
\hline
\end{tabular}

Note: The dependent variable is voter turnout, as measured by the number of voters on the number of individuals eligible to vote. We control for province fixed effects and for electoral year dummies (not reported) in all the regressions were turnout is observed for more than one year. Standard errors (corrected for heteroskedasticity) are reported in parenthesis. The symbols $* * *, * *, *$ indicate that coefficients are statistically significant respectively at the 1,5 , and 10 percent level. 
Table 5. Province fixed effects estimates. Voter Turnout and Arbëreshë communities

\begin{tabular}{|c|c|c|c|c|c|c|c|c|}
\hline & \multicolumn{2}{|c|}{$\begin{array}{c}\text { Referenda } \\
\text { (2011) }\end{array}$} & \multicolumn{2}{|c|}{$\begin{array}{c}\text { European Elections } \\
(1979-2014) \\
\end{array}$} & \multicolumn{4}{|c|}{$\begin{array}{c}\text { General Elections } \\
(1946-2008) \\
\end{array}$} \\
\hline & (1) & (2) & (3) & (4) & (5) & (6) & (7) & (8) \\
\hline Radius & $30 \mathrm{~km}$ & $60 \mathrm{~km}$ & $30 \mathrm{~km}$ & $60 \mathrm{~km}$ & $30 \mathrm{~km}$ & $60 \mathrm{~km}$ & $30 \mathrm{~km}$ & $60 \mathrm{~km}$ \\
\hline \multirow[t]{2}{*}{ Arbëreshë } & $0.0231 * * *$ & $0.0179 * *$ & $0.0265^{* * *}$ & $0.0226^{* * *}$ & $0.0109 * * *$ & $0.0110 * * *$ & $0.0208^{* * *}$ & $0.0207 * * *$ \\
\hline & $(0.00896)$ & $(0.00903)$ & $(0.00613)$ & $(0.00607)$ & $(0.00340)$ & $(0.00347)$ & $(0.0778)$ & $(0.00491)$ \\
\hline \multirow[t]{2}{*}{ Time Trend } & & & & & & & $-0.0034 * * *$ & $-0.0033^{* * *}$ \\
\hline & & & & & & & $(0.00008)$ & $(0.00007)$ \\
\hline \multirow[t]{2}{*}{ Trend*Arbreshe } & & & & & & & -0.0003 & -0.0003 \\
\hline & & & & & & & $(0.0002)$ & $(0.0002)$ \\
\hline Locality FE & prov & prov & prov & prov & prov & prov & prov & prov \\
\hline Time FE & no & no & year & year & year & year & no & no \\
\hline $\mathrm{N}$ & 820 & 554 & 6553 & 4407 & 10174 & 6631 & 6631 & 10174 \\
\hline r2 & 0.319 & 0.408 & 0.297 & 0.255 & 0.473 & 0.476 & 0.382 & 0.374 \\
\hline
\end{tabular}

Notes: The dependent variable is voter turnout, as measured by the number of voters on the number of individuals eligible to vote. We control for province fixed effects and for electoral year dummies (not reported) in all the regressions were turnout is observed for more than one year (with the exception of column 4). Standard errors (corrected for heteroskedasticity and clustered at the municipality level) are reported in parenthesis. The symbols $* * *, * *, *$ indicate that coefficients are statistically significant respectively at the 1,5 , and 10 percent level 
Table 6. IV Estimates. Arbëreshë and Voter Turnout

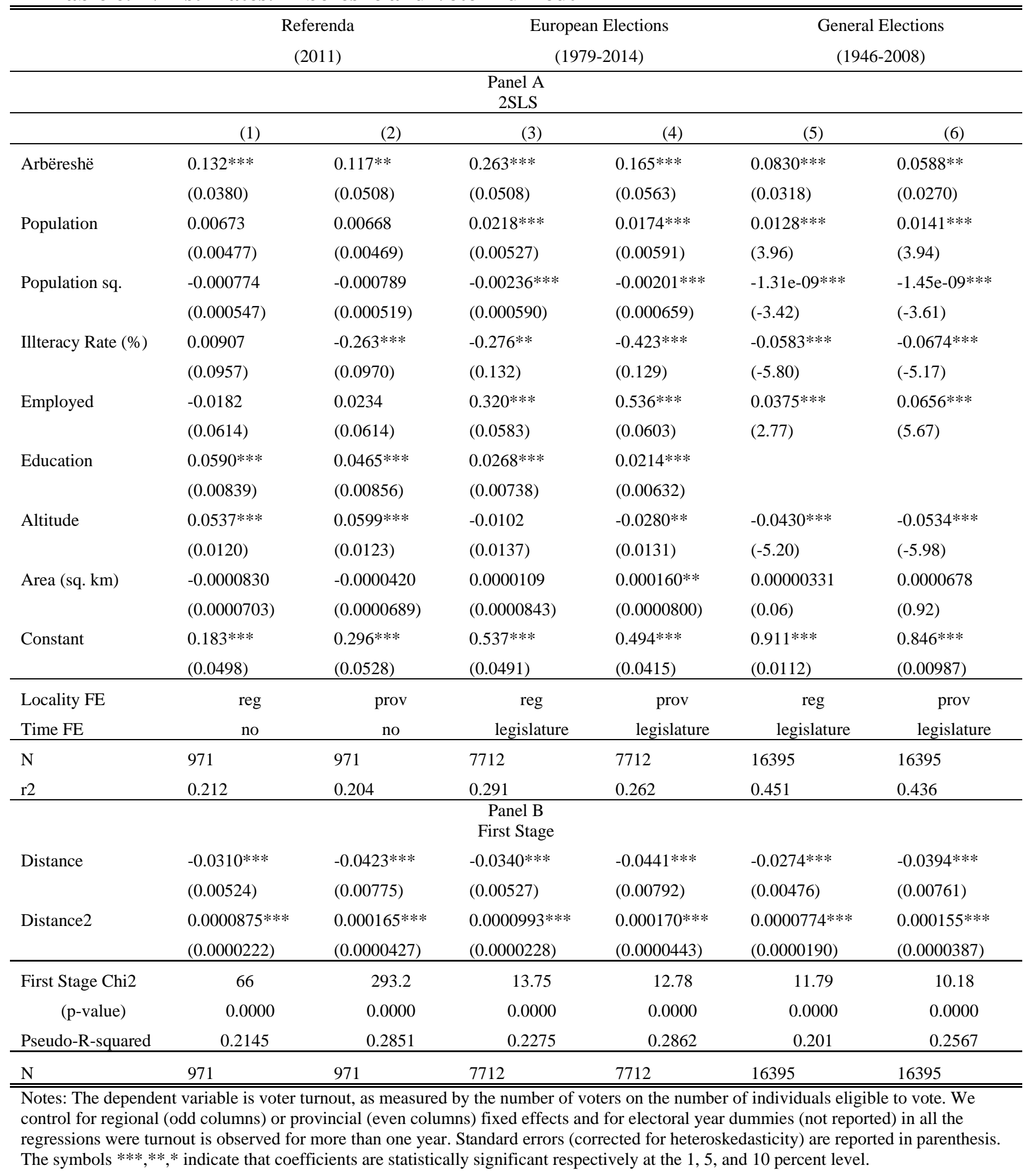


TABLE 7. Additional Robustness Checks

\section{PANEL A Maintenance of Language}

\begin{tabular}{lcc} 
& Referenda & EU \\
Arbëreshë Intensity & $0.037^{* * *}$ & $0.042^{* * *}$ \\
& {$[0.011]$} & {$[0.008]$} \\
R2 & 0.301 & 0.323 \\
\hline \hline
\end{tabular}

PANEL B Greek Communities

$\begin{array}{lcc} & \text { Referenda } & \text { EU } \\ \text { Arbëreshë } & 0.024^{* * *} & 0.026^{* * *} \\ & {[0.009]} & {[0.006]} \\ \text { Greek Communities } & -0.026 & 0.014 \\ & {[0.019]} & {[0.009]}\end{array}$

R2 $0.301 \quad 0.322$

PANEL C Orthodox vs Non-Orthodox Villages

\begin{tabular}{lcc} 
& Referenda & EU \\
Arbëreshë (Orthodox) & $0.031^{* * *}$ & $0.034^{* * *}$ \\
& {$[0.012]$} & {$[0.008]$} \\
Arbëreshë (Non-Orthodox) & $0.022^{*}$ & $0.020^{* *}$ \\
& {$[0.013]$} & {$[0.009]$} \\
R2 & 0.301 & 0.323 \\
\hline
\end{tabular}

Notes: The dependent variable is voter turnout, as measured by the number of voters on the number of individuals eligible to vote. All models include province fixed effects and for electoral year dummies (not reported) in all the regressions were turnout is observed for more than one year. All other controls as in table 4. Standard errors (corrected for heteroskedasticity and clustered at the municipality level) are reported in parenthesis. The symbols $* * *, * *, *$ indicate that coefficients are statistically significant respectively at the 1,5 , and 10 percent level. 
TABLE 8. Arbëreshë and Tax Compliance

\begin{tabular}{lccccc}
\hline \hline & \multicolumn{3}{c}{ OLS } & \multicolumn{2}{c}{ 2SLS } \\
\hline Arbrëshë & $(1)$ & $(2)$ & $(3)$ & $(4)$ & $(5)$ \\
& $0.001^{* * *}$ & $0.002^{* * *}$ & $0.001^{* *}$ & $0.104^{* * *}$ & $0.108^{* *}$ \\
\hline $\mathrm{N}$ & $(0.001)$ & $(0.001)$ & $(0.001)$ & $(0.036)$ & $(0.047)$ \\
$\mathrm{r}^{2} /$ Pseudo-r & 972 & 972 & 972 & 973 & 973 \\
Locality FE & 0.045 & 0.129 & 0.200 & 0.244 & 0.295 \\
\hline First Stage F-stat & none & reg & prov & reg & prov \\
\hline
\end{tabular}

Note: The dependent variable is the TV Licence compliance rate. Locality fixed effects as reported. OLS estimates in columns (1)(3). IV estimates in column (4) and (5). Controls as in Table 3, col (2) and (4). Standard errors (corrected for heteroskedasticity) in parenthesis. The symbols $* * *, * * *$ indicate that coefficients are statistically significant respectively at the 1,5 , and 10 percent level.

Figure 1: Panel (a): Map of Italy, with regional borders. In red: regions with Arbreshe settlements, including provincial (sub-regional) borders. Panel (b): regions with Arbreshe settlements, with (in blue) Arbreshe villages and (green $\mathrm{X}$ ) location of seminaries.

(a)

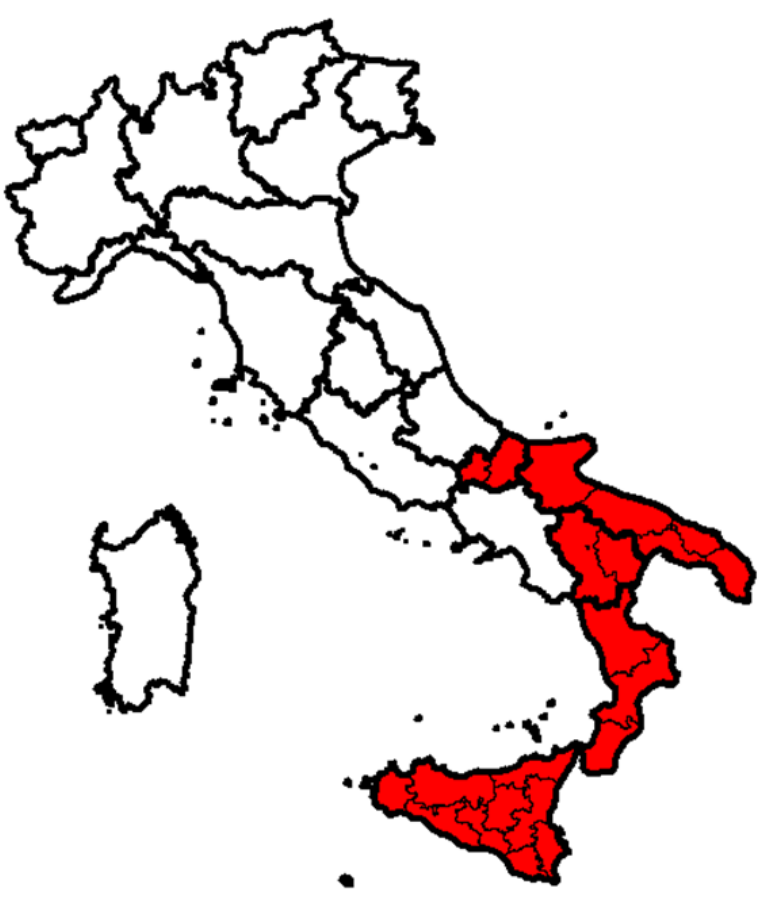

(b)

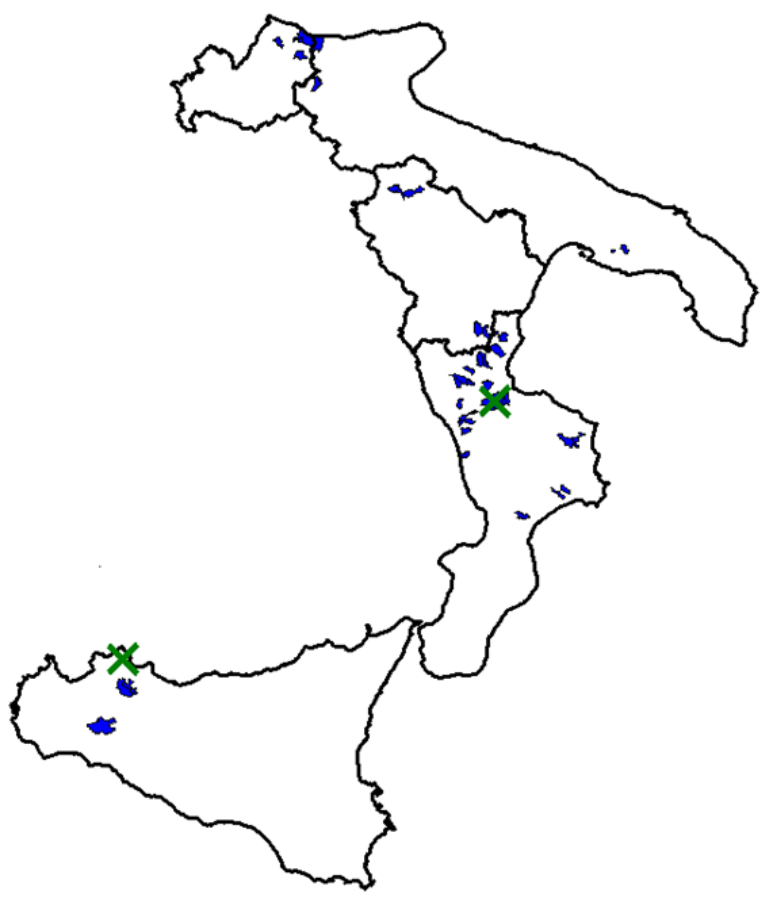


